\title{
Abréviations utilisées
}

\author{
BHR Bibliothèque d'Humanisme et Renaissance \\ BSHPF Bulletin de la Société de l'Histoire du Protestantisme \\ Français \\ HR Humanisme et Renaissance \\ $M L N \quad$ Modern Language Notes \\ RSS Revue du Seizième Siècle
}

(xxv) 
